Available Online at ESci Journals

Journal of Plant Breeding and Genetics

ISSN: 2305-297X (Online), 2308-121X (Print)

http://www.escijournals.net/JPBG

\title{
COMBINING ABILITY ANALYSIS AND GENE ACTION FOR YIELD AND YIELD RELATED TRAITS IN RICE (ORYZA SATIVA L.) UNDER SALINE CONDITIONS
}

\author{
a,cSieh S. Kargbo*, aFrancis Showemimo, bPius Akintokun, aJustina Porbeni \\ a Department of Plant Breeding and Seed Technology, College of Plant Science and Crop Production, Federal University of \\ Agriculture, Abeokuta, Nigeria. \\ b Department of Plant Physiology and Crop Production, College of Plant Science and Crop Production, Federal University \\ of Agriculture, Abeokuta, Nigeria. \\ c Crop Improvement programme, Rokupr Agricultural Research Centre, Sierra Leone Agricultural Research Institute, PMB \\ 1313, Tower Hill, Freetown, Sierra leone.
}

\begin{abstract}
A B S T R A C T
Salinity is a major abiotic constrain faced by farmers in most rice cultivating areas of the world and improving grain yield in rice is the most important breeding objective. Twenty seven hybrids were generated in a line $\mathrm{x}$ tester mating design and were evaluated with their parents in a Randomized Complete Block Design at the Fadama site of the Federal University of Agriculture, Abeokuta (FUNAAB) during the 2014/2015 and 2015/2016 cropping season. Analysis of variance revealed a highly significant difference $(\mathrm{P}<0.01)$ among testers and lines for all traits except panicle length and a number of effective tillers per plant, respectively. Variances of Specific Combining Ability (SCA) were higher in magnitude than the corresponding General Combining Ability (GCA). The lines FARO $60 \quad\left(\mathrm{P}_{7}\right)$, OG300315 $\left(\mathrm{P}_{10}\right)$, NERICA L53 $\left(\mathrm{P}_{4}\right)$ including a tester ITA $212\left(\mathrm{P}_{1}\right)$ were the best general combiners for yield per plant. POKKALI $\left(\mathrm{P}_{3}\right)$ was the best general combiner for reduced vegetative growth and ITA $212\left(\mathrm{P}_{1}\right)$ and ITA $222\left(\mathrm{P}_{2}\right)$ were the best general combiners for plant height. The best specific combiner for yield per plant was $\mathrm{P}_{1} \times \mathrm{P}_{4}$. $\mathrm{P}_{3} \times \mathrm{P}_{11}$ was the best specific combiner for reduced duration characters and $\mathrm{P}_{2} \times \mathrm{P}_{7}$ was the best specific combiner for plant height. Estimates of narrow sense heritability $(0.00-0.03)$ for all the traits under study were low which indicated preponderance of non-additive gene action governing these traits. Therefore, inter-mating among selected segregants followed by recombination breeding in an advanced generation might be advocated for improvement of the studied traits under salinity.
\end{abstract}

Keywords: Rice (Oryza sativa L.), Line x tester, Specific Combining Ability, General Combining Ability, gene action, salinity tolerance.

\section{INTRODUCTION}

The line $\mathrm{x}$ tester analysis method is used to breed both self and cross-pollinated plants and to estimate favourable parents and crosses, and their general and specific combining abilities (Aslam et al., 2014; Asadur Rahmann, 2016). The success of a plant breeding program greatly depends on the right choice of parents for hybridization and the gene action of different economic traits. According to Patial et al., (2016), combining ability gives useful information on the choice of parents in terms of expected performance of the

* Corresponding Author:

Email: siehskargbo@gmail.com

(C) 2019 ESci Journals Publishing. All rights reserved. hybrids and their progenies. Per se Performances do not necessarily reveal which parents are good or poor combiners. Therefore, gathering information on the nature of gene effects and their expression in terms of combining ability is necessary. Combining ability helps to define the pattern of gene effects in the expression of quantitative traits by identifying potentially superior parents and hybrids (Zhang et al., 2015).

General Combining Ability (GCA) is attributed to additive gene effects and additive $\mathrm{x}$ additive epistasis and is theoretically fixable. On the other hand, Specific Combining Ability (SCA) attributable to non-additive gene effect and may be due to dominance or epistasis or both which is non-fixable (Koze, 2017). The presence of 
non-additive genetic variance is the primary justification for initiating the hybrid program (Pradhan and Singh et al., 2008). The preponderance of non-additive gene action in the expression of yield and yield-related traits was reported by Thirumalai et al., (2018). Line X tester design is the best analysis for estimating GCA, SCA and various types of gene actions (Fahmi et al., 2017).

Breeding rice varieties to overcome salinity stress is the most promising, less resource consuming, economically viable and socially acceptable approach. Salt tolerance is a polygenic trait that allows plants to grow and maintain economic yield in the presence of non-physiological high and relatively constant levels of salt. The importance of developing genotypes that are tolerant to salinity with increased yield will be useful. To establish a yield improvement programme in rice, information about per se performance, combining ability effects of parents and hybrids and the magnitude of gene action involved in the inheritance of quantitative traits is important (Gopikannan and Ganesh, 2013). The objectives of this study were to determine the combining ability and genetic variance components for yield and related traits in order to help in the selection of parents and assists in the choice of breeding strategies for the improvement of salinity tolerance in rice.

\section{MATERIALS AND METHODS}

Plant Material and Study Area: The present study was carried on Fadama site of Federal University of Agriculture Abeokuta (FUNAAB, Latitude 70 $14 \mathrm{~N}$ and Longitude $3^{\circ} 26$ E) during the 2014/2015 and $2015 / 2016$ cropping season. Average rainfall during the cropping season was $1.3 \mathrm{~mm}$, average minimum and maximum temperatures was $22.6^{\circ} \mathrm{C}$ and $34.1^{\circ} \mathrm{C}$, respectively while relative humidity was $46.3 \%$. Twentyseven hybrids were produced from 12 rice genotypes, at the AfricaRice centre at the International Institute for Tropical Agriculture (IITA, Latitude $3^{\circ} 54 \mathrm{~N}$ and longitude $7^{\circ} 30 \mathrm{~W}$ ), Ibadan. The experimental materials consisted of 9 lines namely: NERICA L53 $\left(\mathrm{P}_{4}\right)$, FARO 44 $\left(\mathrm{P}_{5}\right)$, FARO $52\left(\mathrm{P}_{6}\right)$ and FARO $60\left(\mathrm{P}_{7}\right)$ (Drought, blast and iron toxicity resistant) and OG0315 ( $\left.\mathrm{P}_{8}\right), 0 \mathrm{G} 250315\left(\mathrm{P}_{9}\right)$, OG300315 ( $\left.\mathrm{P}_{10}\right)$, OW0315 ( $\left.\mathrm{P}_{11}\right)$ and OW100315 ( $\left.\mathrm{P}_{12}\right)$ (Mutatant varieties), these were crossed with three salt tolerant testers POKKALI $\left(\mathrm{P}_{3}\right)$, ITA $212\left(\mathrm{P}_{1}\right)$ and ITA 222 $\left(\mathrm{P}_{2}\right)$. The experiment was laid out in a Randomized Complete Block Design with three replications. After creating the bunds, the area of each block was $9.6 \mathrm{~m} \mathrm{X}$
$5.4 \mathrm{~m}$ with a $1 \mathrm{~m}$ distance between each replication and a $0.75 \mathrm{~m}$ distance from the field borders. Each plot area was $0.6 \mathrm{~m} \times 0.5 \mathrm{~m}$ with an inter-plot spacing of $0.4 \mathrm{~m}$. Seedling from the nursery was transplanted after 21 days with one seedling per hill and a spacing of $30 \mathrm{~cm} \mathrm{X}$ $25 \mathrm{~cm}$ between and within rows respectively. The total research area was $174 \mathrm{~m}^{2}$. Nitrogen, phosphorous and potassium (N:P:K-15:15:15) fertilizers was applied at $200 \mathrm{~kg} / \mathrm{ha}$, and urea was applied at the rate of $100 \mathrm{~kg} / \mathrm{ha}$ as top-dressing first at tillering and a second time at booting.

Soil Acclimatization to Salinity: The soil was first treated with ordinary table salt dissolved in water to a salinity level of $6 \mathrm{ds} / \mathrm{m}$ and the second application of saline water was added after 3 days at a concentration of $2 \mathrm{ds} / \mathrm{m}$, which was applied four consecutive times. Each plot was given $2.5 \mathrm{~L}$ of salt water in each application (Appendix 1).

Data Collection: Data were collected on the following parameters: days to $50 \%$ booting (BTN), days to $50 \%$ flowering (FLW), days to 80\% Anthesis (ANTS), days to 80\% maturity (MTY), Plant height (PLHT), Total number of tillers per plant (TNT), number of effective tillers per plant (EFT), number of non-effective tillers per plant (NEFT), Panicle length (PAN.L), Panicle weight (PAN.W), number of filled grains per panicle (FG), number of unfilled grains per panicle (UFG), percentage fertility (\%F), Seed length (SD.LTH), Seed width (SD.WTH), 1000 grain weight (1000GWH) and yield per plant (Y/PLT).

Statistical Analysis: The mean data were subjected to ANOVA and Combining Ability Analysis using the Line $\mathrm{x}$ Tester procedure developed by Kempthorne (Aslam et al., 2014).

The linear models assumed was: $Y_{i j k}=\mu+g_{i}+g_{j}+S_{i j}+e_{i j k}$ where, $y_{i j k}=$ value of the $i j k^{\text {th }}$ observations of the cross involving $\mathrm{i}^{\text {th }}$ line and $\mathrm{j}^{\text {th }}$ tester in $\mathrm{k}^{\text {th }}$ replication; $\mu=$ general mean (an effect common to all crosses in all the replications); $g_{i}=$ general combining ability (GCA) effect of ith line; $g_{j}=$ general combining ability (GCA) effect of $\mathrm{j}^{\text {th }}$ tester; $\mathrm{S}_{\mathrm{ij}}=$ specific combining ability (SCA) effect of the cross involving $i^{\text {th }}$ line and $j^{\text {th }}$ tester; $e_{i j k}=$ error associated with $\mathrm{i}^{\text {th }}$ observation. $\mathrm{i}=\mathrm{i}^{\text {th }}$ line $(1,2,3) ; \mathrm{j}=\mathrm{j}^{\text {th }}$ tester $(1,2,3,4)$ and $\mathrm{k}=\mathrm{k}^{\text {th }}$ replication.

The variances for general and specific combining abilities, error variances, were derived from the analysis of variance of the different traits as suggested by Fellahi et al (2013): 
Covariance of Half sibs (average): $\frac{M_{l}-M_{l X t}}{r t}$

Covariance of Half sibs (testers): $\frac{M_{t}-M_{l X t}}{r l}$

Covariance of Half sibs (average): $\frac{1}{r(2 l t-l-t)}\left[\frac{(l-1)\left(M_{l}\right)+(t-1)\left(M_{t}\right)}{l+t-2}-M_{L X t}\right]$

Covariance of full sibs: $\quad \frac{\left(M_{l}-M_{e}\right)+\left(M_{t}-M_{e}\right)+\left(M_{l X t}-M_{e}\right)}{3 r}+\frac{6 r \text { Cov.H.S. }-r(l+t) \text { Cov.H.S }}{3 r}$

Variances due to general and specific combining ability where calculated as:

$\sigma^{2}$ gca $=$ Cov.H.S $=\left(\frac{1+F}{4}\right) \sigma_{A}^{2}$

$\sigma^{2} \mathrm{sca}=\left(\frac{1+F}{2}\right) \sigma_{D}^{2}$

Additive and dominant genetic variances $\left(\sigma^{2} \mathrm{~A}\right.$ and $\left.\sigma^{2} \mathrm{D}\right)$ were calculated by taking the inbreeding coefficient $(\mathrm{F})$ as zero; that is, $\mathrm{F}=0$ because both lines and testers were not inbred lines.

Significance test for general combining ability and specific combining ability effects were performed using $t$-test. Narrow sense heritability was estimated, after derivation of the variance components (Gholizadeh et al., 2014). $\left(\sigma^{2}\right.$ gca $/ \sigma^{2}$ sca $)$, and $\left(\sigma^{2} D / \sigma^{2} A\right)^{1 / 2}$ ratios were used to rate the relative weight of additive versus the nonadditive type of gene actions (Vema and Srivastava, 2004).

\section{RESULTS AND DISCUSSION}

The analysis of variance for combining abilities showed significant differences among genotypes for all traits studied, suggesting variability among the genotypes. The Mean squares of rice genotypes for these traits were portioned into parents, hybrids and parents $\mathrm{x}$ hybrids, which revealed highly significant differences among themselves. Significant differences were observed among the lines and testers for all traits studied except effective tillers per plant and panicle length (Vanave et al., 2018). Thus indicating the prevalence of additive variance. Significant differences due to the interactions of line $\mathrm{x}$ tester for all the characters indicated the importance of both additive and non-additive variances. The differences between the mean average performance of all the hybrids with the mean performance of POKKALI $\left(\mathrm{P}_{3}\right)$ a well known salinity tolerant genotype, shows that on average POKKALI had a better performance than the hybrids in the following traits $50 \%$ booting ( -4.38 days), $50 \%$ flowering ( -4.31 days), $80 \%$ anthesis (-6.56days), number of effective tillers per plant (7.34), number of non-effective tillers per plant ($12.59)$, panicle length $(1.68 \mathrm{~cm})$, panicle weight $(1.64 \mathrm{~g})$, number of filled grains per panicle (36.98), number of unfilled grains per panicle (-59.85), \%fertility (33.58\%), seed length $(0.15 \mathrm{~mm})$, seed width $(0.64 \mathrm{~mm}), 1000$ grain weight $(1.13 \mathrm{~g})$ and yield per plant $(13.62 \mathrm{~g} / \mathrm{ha})$, while these characters $80 \%$ maturity ( 0.9 days), plant height $(8.8 \mathrm{~cm})$ and total number of tillers per plant (4.83) were in favour of the hybrids.

Genetic variability and mean performance of parents and hybrids are important criteria for genotypic evaluation; however, the parents with high mean value may not transmit this characteristic to their hybrids (Fellahi et al., 2013). The negative general combining ability variance $\left(\sigma^{2} \mathrm{gca}\right.$ ) values for both lines and testers in some characters indicates the accessibility of additive gene action in those traits. Variances due to specific 
combining ability ( $\left.\sigma^{2} s c a\right)$ were higher in magnitude than the corresponding variances due to general combining ability $\left(\sigma^{2}\right.$ gca) for all the traits which indicated the preponderance of non-additive gene action in their inheritance which might be as a result of dominance, epitasis and interaction effects. Similar results of the predominance of $\sigma^{2}$ sca variance over $\sigma^{2}$ gca have been observed by Thirumalai et al. (2018) for barley. The dominance of genetic variance was larger than the additive genetic variance for all traits. These results are further supported by the low magnitude of $\sigma^{2} \mathrm{gca} / \sigma^{2} \mathrm{sca}$ ratio coupled with a partial degree of dominance for almost all the characters. Premlatha et al. (2011) reported the importance of non additive gene action for plant height and grain yield. Gnanasekaran et al. (2006) reported non additive gene action for seed weight and plant height. The result of this study was in contrast with Borghi and Perenzin (1994) who observed that $\sigma^{2}$ gca was of greater importance than $\sigma^{2}$ sca for the majority of yield characters. Predominance of non-additive genetic variance indicated the presence of heterozygosity in the population. As such, this type of genetic variance is nonfixable and thus the development of hybrids is also an appropriate crop improvement tool. But rice, being a self-pollinated crop, heterosis is not widely adopted unlike recombination breeding because of the stress involved in the synthesis of hybrids. Preponderance of non-additive gene action in terms of yield components was also reported by Shanthi et al., 2011. Panicle length and seed width both had a magnitude of 0.00 gene action, additive variances of 0.00 with the lowest dominance variance of 0.82 and 0.35 , respectively among all the characters studied. This indicates that both of these characters possess heterozygous alleles which are positive and negative thus leading to small dominance values. In all cases, low narrow sense heritability $\left(h^{2} n\right)$ was obtained $(0.00-0.03)$, indicating that non-additive gene effects play an important role in controlling the studied traits. Ahmadikhah, 2008 reported a low specific heritability for yield-related traits. Gholizadeh et al., (2014) also demonstrated that the lower narrow sense heritability was caused by low additive gene effects and high dominant gene action. Heritability in broad sense estimates ranged from 0.49 to 1.00 , which showed that some traits were highly influenced by the environment (salinity) while other traits revealed a substantial contribution of additive variance in their expression. Therefore, it appears that hybridization must be a choice for utilizing the special hybrids in the population. Also the, estimated genetic advance for traits showed the ability to improve most traits exists, inorder to obtain suitable lines with high yield. The results suggest that improvement in these traits may be obtained through single plant selection in later generations followed by hybridization or intermating of selected segregants through recurrent selection. Similar results were observed previously by Manickavelu, et al. (2006), pradhan, et al. (2006) and Sarma, et al. (2007).

The proportional contribution of lines, testers and their interaction for 17 characters was evident that lines played an important role towards panicle length $(62.63 \%)$ and yield per plant (43.27\%), this is an indication that lines contributed more positive alleles for these traits and so might be under the maternal influence. Testers were more important for $50 \%$ booting (68.91\%), 50\% flowering (62.25\%), 80\% anthesis (60.47\%), non-effective tillers (43.67\%), panicle weight (42.27\%), filled grains (56.17) and unfilled grains (60.18\%). The proportional contribution to the total variation of the testers was the highest followed by line $\mathrm{x}$ testers interaction. The contribution of line $\mathrm{x}$ tester interaction was important for $80 \%$ maturity $(47.90 \%)$, plant height (35.74\%), total number of tillers (40.45\%), seed length (42.23\%), seed width (63.35\%) and 1000GWH (51.72\%).

The estimates of general combining ability effects are considered as an important indicator of the potential of parental lines for generating superior breeding populations. The GCA effect is considered an intrinsic genetic value of the parent for a trait, which is due to additive gene effects and it is fixable (Simmonds, 1989). Estimates of general combining ability effect showed that it was not possible to select a good general combiner because no one parent had a high significant GCA effect for all the 17 yield and its related characters. A negligible or negative combining ability effect indicates a poor ability to transfer its genetic superiority to hybrids. The largest significant positive values have the largest effects. On the other hand, the largest significant negative values have the smallest effects, except in the case of unfilled grains per panicle, noneffective tillers per plant, duration (days) and plant height characters. Minimum plant height is needed to protect the plant from lodging. Therefore, ITA 212 and ITA 222, male parents had highly significant GCA effect 
in the desirable direction (negative direction). Pokkali a potential male parent also had highly significant GCA effect for duration characters (negative direction), short duration are desirable characters in genotypes when breeding for salinity tolerance. The lines Nerica L-53, FARO 60 and OG300315 had highly significant GCA effect for filled grain per panicle, fertility percentage and yield per plant. ITA 212 was the only potential male parent with highly significant GCA effect for filled grains per panicle, fertility percentage and yield per plant. It was noticed that these parents did not transmit these characters in the desired direction in most of the hybrids. Singh and Singh (1985) suggested that parents with high GCA would produce transgressive segregants in $F_{2}$ or later generations. Hence, the lines and testers with high GCA effects in the desired direction may be utilized in hybridization programme to improve salt tolerant traits through transgressive breeding. Thus, an overview of mean performance and GCA effects of parents revealed that multiple crosses involving ITA 212, POKKALI, NERICA L53, FARO 60 and OG300315 would be considered as invaluable sources of genetic materials as they might throw desirable segregants possessing salinity tolerance coupled with high yield performance.

In the present study, none of the cross combinations exhibited high specific combining ability effects for all the 17 characters under salinity. Vanave et al., 2018 also reported that no specific cross combination was desirable for all the traits in their study. About $15 \%$ of hybrids showed a significant desirable effect for yield per plant along with two important traits viz filled grains per panicle and fertility percentage, which indicated that it would be a good idea to give preference to these hybrids alongside these traits when selecting for yield under salinity. The hybrids exhibiting significant and desirable SCA effect for these characters were $\mathrm{P}_{1} \times \mathrm{P}_{4}, \mathrm{P}_{1}$ $x \mathrm{P}_{10}, \mathrm{P}_{1} \times \mathrm{P}_{12}$, and $\mathrm{P}_{2} \times \mathrm{P}_{9}$. For duration characters high significant SCA effects were pronounced in two hybrids $\mathrm{P}_{1} \mathrm{X} \mathrm{P}_{9}$ and $\mathrm{P}_{2} \times \mathrm{P}_{5}$. These hybrids would produce high yielding and early duration segregates in later generations. Similar findings were observed by Kumar et al. (2010) for days to $50 \%$ flowering. The hybrids $\mathrm{P}_{3} \times \mathrm{P}_{8}$ and $\mathrm{P}_{3} \times \mathrm{P}_{11}$ were sterile but days to maturity was recorded for them when $80 \%$ of their Spikelets turned yellowish brown in the field, it was observed that both of them matured earlier before all the other hybrids. The hybrids $\mathrm{P}_{1} \times \mathrm{P}_{5}, \mathrm{P}_{1} \times \mathrm{P}_{6}, \mathrm{P}_{1} \times \mathrm{P}_{11}$ and $\mathrm{P}_{2} \times \mathrm{P}_{7}$ possessed considerable SCA effect for dwarfness. It was observed that parents of all the hybrids were of one good and one poor combiner, indicated the presence of dominance gene action. Therefore, these hybrids are recommended for heterosis breeding, because the usefulness of a particular cross in the exploitation of heterosis is judged by specific combining ability effect. While considering the SCA effect for fertility percentage the hybrid $\mathrm{P}_{3} \times \mathrm{P}_{7}$ had one of the highest significant SCA effect coupled with yield per plant though it had a negative insignificant SCA effect for filled grain per panicle. It is obvious that the best cross combination are not found between high $\mathrm{x}$ high general combiners but may also occur in other types of parental combinations. Usually, it's expected that a combination of two good general combiners should throw some useful transgressive segregants, but this is not normally the case. An example of this is the cross combination $\mathrm{P}_{2} \times \mathrm{P}_{9}$ which has a highly significant SCA effect for yield per plant, which was derived from a combination of two poor general combiners. Such behaviour has been attributed to over dominance or epistasis (Devi et al., 2017). The superiority of average $\mathrm{x}$ average combinations might be due to the concentration and/or interaction between favourable genes contributed by parents. Peng and Virmani (1990) also reported the interaction between positive alleles for good combiner and negative alleles for poor combiners which suggested for the exploitation of heterosis in $F_{1}$ generation as their potential would be unfixable in succeeding generation.

\section{CONCLUSION}

This study indicated that gene action and both general and specific combining ability effects are important but the predominance of non-additive genetic variance shows the presence of heterozygosity in the population. According to the overall performance across the 17 characters, the testers, followed by NERICA L53, FARO 60 and OG300315 were identified as most promising parents due to having good general combining ability effect for yield per plant and almost all it major components under salinity stress. However, on the basis of per se performance and SCA effect the following cross combination will be promising viz $\mathrm{P}_{1} \times \mathrm{P}_{4}, \mathrm{P}_{1} \times \mathrm{P}_{10}, \mathrm{P}_{1} \times$ $\mathrm{P}_{12}$ and $\mathrm{P}_{3} \times \mathrm{P}_{7}$ for yield per plant, $\mathrm{P}_{1} \times \mathrm{P}_{9}$ and $\mathrm{P}_{2} \times \mathrm{P}_{5}$ for earliness and $\mathrm{P}_{1} \times \mathrm{P}_{5}, \mathrm{P}_{1} \times \mathrm{P}_{6}$ and $\mathrm{P}_{1} \times \mathrm{P}_{11}$ for plant height. These hybrids have potential as high yielding salinity tolerant genotypes, therefore recommend for hybrid production for seed companies. 
Table 1. Analysis of variance for line $\mathrm{x}$ tester of mean squares values for agronomic traits studied.

\begin{tabular}{|c|c|c|c|c|c|c|c|c|c|c|c|c|c|c|c|c|c|c|}
\hline SV & $\mathrm{df}$ & BTN & FLW & ANTS & MTY & PLHT & TNT & EFT & NEFT & PAN.L & PAN.W & FG & UFG & F\% & SD.LHT & SD.WTH & 1000GWH & Y/PLT \\
\hline Block & 2 & 8.80 & 2.57 & 6.78 & 0.23 & 55.46 & $769.8^{* *}$ & 109.58* & 302.58 & 2.49 & 0.41 & $3048.5^{* *}$ & 275.01 & $597.33^{* *}$ & 0.05 & 0.01 & $0.14^{* *}$ & 1.86 \\
\hline Geno. & 38 & $281.05^{* *}$ & $325.73^{* *}$ & $314.22 * *$ & $3390.15^{* *}$ & $1351.29^{* *}$ & $537.5^{* *}$ & $143.43^{* *}$ & $920.83^{* *}$ & $9.13^{* *}$ & $5.81^{* *}$ & $10687.79^{* *}$ & $12600.57^{* *}$ & $2544.458^{* *}$ & $34.39 * *$ & $3.7^{* *}$ & $345.41^{* *}$ & $164.5^{* *}$ \\
\hline Parents & 11 & $374.45^{* *}$ & $428.31^{* *}$ & $426.09^{* *}$ & $5569.66^{* *}$ & $1229.48^{* *}$ & $900.22^{* *}$ & $129.11^{* *}$ & $1572.79 * *$ & $12.53^{* *}$ & $11.66^{* *}$ & $18268.65^{* *}$ & $14498.76^{* *}$ & $2474.72^{* *}$ & $59.04^{* *}$ & $6.65^{* *}$ & $568.84^{* *}$ & $293.39^{* *}$ \\
\hline PXC & 1 & 822.25 & 816.96 & 1606.17 & 24013.12 & 2386.58 & 243.79 & 634.15 & 1664.33 & 4.15 & 1.20 & 12981.28 & 59876.50 & 12585.34 & 157.04 & 14.55 & 1640.19 & 101.70 \\
\hline Crosses & 26 & $220.71^{* *}$ & $263.43^{* *}$ & $217.21^{* *}$ & $1674.86^{* *}$ & $1363.01^{* *}$ & $395.35^{* *}$ & $130.62^{* *}$ & $616.4^{* *}$ & $7.88^{* *}$ & $3.51^{* *}$ & $7392.29 * *$ & $9979.19^{* *}$ & $2187.76^{* *}$ & $19.25^{* *}$ & $2.04^{* *}$ & $201.08^{* *}$ & $112.38^{* *}$ \\
\hline Line & 8 & $69.42^{* *}$ & $114.27^{* *}$ & $93.08^{* *}$ & $1233.4^{* *}$ & $1422.55^{* *}$ & $433.16^{* *}$ & 40.01 & $604.67^{* *}$ & $16.04^{* *}$ & $4.34^{* *}$ & $8052.45 * *$ & $4181.68^{* *}$ & $1606.07^{* *}$ & $17.14^{* *}$ & $1.87^{* *}$ & 201.23** & $158.02^{* *}$ \\
\hline Tester & 2 & 1977.12** & $2234.68^{* *}$ & $1707.37^{* *}$ & $6410.46^{* *}$ & $5695.87^{* *}$ & $1312.53^{* *}$ & $558.62^{* *}$ & $3499.03^{* *}$ & 2.1 & $19.29^{* *}$ & $53977.37^{* *}$ & $78067.6^{* *}$ & 18759.03** & $76^{* *}$ & $2.29^{* *}$ & $456.99 * *$ & $412.89^{* *}$ \\
\hline LXT & 16 & $76.8^{* *}$ & $91.61^{* *}$ & $93^{* *}$ & $1303.64^{* *}$ & 791.63** & $261.79^{*}$ & $122.42^{* *}$ & $261.94^{*}$ & $4.53^{*}$ & $1.12^{* *}$ & $1239.07^{* *}$ & $4366.89^{* *}$ & $408.2^{* *}$ & $13.21^{* *}$ & $2.10^{* *}$ & $169.01^{* *}$ & $52.00^{* *}$ \\
\hline Error & 76 & 13.95 & 8.62 & 9.09 & 11.28 & 44.98 & 119.69 & 33.45 & 107.58 & 2.59 & 0.31 & 194.24 & 339.27 & 60.60 & 0.04 & 0.00 & 0.03 & 1.23 \\
\hline
\end{tabular}

*: significant at $\mathrm{p}<0.05 ;{ }^{* *}$ : significant at $\mathrm{p}<0.01$.

BTN $=$ days to $50 \%$ booting, FLW $=$ days to $50 \%$ flowering, ANTS $=$ days to $80 \%$ Anthesis, MTY $=$ days to $80 \%$ maturity, PLHT $=$ Plant height $(\mathrm{cm})$, TNT $=$ Total number of tillers, EFT $=$ number of effective tillers, NEFT = number of non-effective tillers, PAN.L $=$ Panicle length $(\mathrm{cm})$, PAN.W $=$ Panicle weight $(\mathrm{g}), \mathrm{FG}=$ number of filled grains per panicle, $\mathrm{UFG}=$ number of unfilled grains per panicle, $\% \mathrm{~F}=$ percentage fertility, SD.LHT $=$ Seed length $(\mathrm{mm})$, SD.WTH $(\mathrm{mm})=$ Seed width, $1000 \mathrm{GWH}=1000 \mathrm{grain}$ weight $(\mathrm{g})$, $\mathrm{Y} / \mathrm{PLT}=$ yield per plant $(\mathrm{g} / \mathrm{ha})$.

Table 2. Mean performance and standard error for parents and hybrids for agronomic traits studied

\begin{tabular}{|c|c|c|c|c|c|c|c|c|c|c|c|c|c|c|c|c|c|}
\hline PARENTS & BTN & FLW & ANTS & MTY & PLHT & TNT & EFT & NEFT & PAN.L & PAN.W & $\mathrm{FG}$ & UFG & F\% & SD.LHT & SD.WTH & $1000 \mathrm{GWH}$ & Y/PLT \\
\hline $\mathrm{P} 1$ & $\overline{73.67}$ & $\overline{82.33}$ & 84.67 & $\overline{105.00}$ & 115.07 & $\overline{36.30}$ & $\overline{27.73}$ & 8.53 & 23.03 & 4.50 & $\overline{173.00}$ & 24.80 & $\overline{86.27}$ & 9.35 & 2.53 & 26.47 & 36.04 \\
\hline P2 & 71.33 & 80.00 & 82.33 & 102.00 & 99.53 & 29.63 & 26.77 & 2.83 & 25.23 & 4.17 & 180.60 & 31.40 & 85.17 & 9.29 & 2.39 & 24.53 & 36.11 \\
\hline P3 (T.C) & 48.00 & 54.67 & 57.33 & 80.00 & 125.73 & 28.30 & 18.87 & 9.40 & 26.77 & 3.30 & 105.60 & 29.00 & 78.57 & 8.64 & 3.40 & 27.60 & 19.67 \\
\hline P4 & 60.00 & 75.33 & 78.67 & 104.00 & 94.30 & 26.83 & 17.83 & 8.97 & 22.27 & 1.57 & 64.80 & 49.60 & 56.23 & 9.87 & 2.41 & 23.87 & 9.68 \\
\hline P5 & 70.00 & 75.67 & 78.67 & 102.67 & 106.97 & 31.50 & 24.63 & 6.87 & 21.90 & 1.90 & 87.40 & 52.80 & 62.30 & 9.31 & 2.51 & 26.03 & 18.07 \\
\hline P6 & 68.67 & 76.00 & 80.33 & 105.33 & 119.33 & 25.07 & 18.53 & 6.53 & 21.77 & 3.07 & 122.40 & 31.20 & 78.30 & 8.38 & 2.25 & 21.60 & 23.21 \\
\hline P7 & 74.33 & 81.33 & 83.67 & 102.33 & 141.53 & 25.17 & 17.20 & 7.93 & 26.77 & 3.87 & 152.20 & 29.20 & 83.83 & 9.59 & 2.25 & 16.83 & 26.29 \\
\hline P8 & 65.33 & 68.67 & 72.33 & 94.67 & 140.07 & 18.87 & 18.53 & 0.30 & 24.83 & 3.90 & 105.00 & 8.20 & 92.83 & 8.50 & 3.86 & 32.43 & 41.39 \\
\hline P9 & 64.33 & 70.67 & 74.33 & 93.67 & 134.20 & 12.60 & 11.50 & 1.10 & 23.97 & 3.20 & 95.80 & 34.00 & 73.53 & 8.20 & 3.65 & 29.17 & 16.82 \\
\hline P10 & 57.33 & 64.00 & 67.67 & 87.67 & 147.20 & 23.17 & 16.40 & 6.77 & 24.80 & 2.23 & 70.00 & 45.20 & 60.43 & 8.69 & 3.71 & 29.30 & 19.79 \\
\hline P11 & 61.67 & 67.00 & 70.67 & 88.67 & 124.20 & 17.40 & 17.40 & 0.00 & 23.00 & 4.87 & 145.00 & 12.20 & 91.60 & 8.56 & 3.63 & 30.50 & 38.65 \\
\hline $\mathrm{P} 12$ & 59.67 & 68.00 & 71.67 & 93.00 & 126.50 & 13.63 & 8.40 & 5.17 & 22.43 & 3.50 & 86.40 & 26.40 & 71.33 & 8.15 & 3.39 & 28.33 & 20.83 \\
\hline \multicolumn{18}{|l|}{ HYBRIDS } \\
\hline P1 x P4 & 64.67 & 80.00 & 84.67 & 101.00 & 126.63 & 42.33 & 18.87 & 23.43 & 26.93 & 4.12 & 200.40 & 29.80 & 87.10 & 9.90 & 2.79 & 28.17 & 20.24 \\
\hline P1 x P5 & 57.33 & 62.00 & 65.33 & 83.33 & 88.53 & 23.23 & 13.10 & 10.13 & 21.37 & 1.30 & 64.60 & 101.00 & 40.23 & 9.81 & 2.73 & 28.63 & 3.97 \\
\hline P1 x P6 & 55.00 & 61.67 & 66.67 & 87.33 & 94.43 & 9.90 & 6.77 & 3.10 & 23.57 & 2.22 & 97.60 & 81.00 & 55.03 & 9.88 & 2.78 & 27.17 & 9.54 \\
\hline P1 x P7 & 66.33 & 72.67 & 76.33 & 93.67 & 147.90 & 17.87 & 15.90 & 2.00 & 27.07 & 4.76 & 158.80 & 59.00 & 73.00 & 9.94 & 2.58 & 26.70 & 15.05 \\
\hline P1 x P8 & 56.33 & 61.67 & 66.00 & 84.33 & 141.77 & 29.77 & 13.57 & 16.20 & 25.90 & 1.12 & 57.60 & 57.40 & 50.53 & 9.28 & 3.03 & 30.10 & 3.47 \\
\hline
\end{tabular}




\begin{tabular}{|c|c|c|c|c|c|c|c|c|c|c|c|c|c|c|c|c|c|}
\hline P1 x P9 & 48.33 & 55.00 & 60.33 & 78.00 & 144.10 & 27.67 & 10.90 & 16.80 & 23.10 & 1.21 & 70.40 & 53.80 & 56.37 & 9.67 & 3.01 & 30.53 & 4.20 \\
\hline $\mathrm{P} 1 \times \mathrm{P} 10$ & 57.00 & 63.67 & 67.00 & 86.67 & 129.23 & 35.90 & 20.53 & 15.33 & 27.77 & 3.04 & 129.00 & 43.00 & 74.97 & 9.63 & 3.20 & 35.20 & 18.36 \\
\hline $\mathrm{P} 1 \times \mathrm{P} 11$ & 62.33 & 69.00 & 72.33 & 89.67 & 104.57 & 30.63 & 11.90 & 18.77 & 23.90 & 2.01 & 87.00 & 38.40 & 69.27 & 9.14 & 2.98 & 26.13 & 3.63 \\
\hline $\mathrm{P} 1 \times \mathrm{P} 12$ & 53.00 & 60.00 & 63.67 & 85.00 & 144.13 & 25.90 & 16.77 & 9.10 & 27.10 & 2.08 & 112.60 & 65.00 & 63.17 & 9.33 & 3.10 & 29.13 & 14.87 \\
\hline P2 x P4 & 64.67 & 71.00 & 75.00 & 91.00 & 110.57 & 36.87 & 15.13 & 21.80 & 25.20 & 2.52 & 94.40 & 62.60 & 60.23 & 9.45 & 2.60 & 28.13 & 3.61 \\
\hline P2 x P5 & 48.67 & 55.67 & 61.00 & 79.67 & 140.20 & 29.00 & 9.77 & 19.23 & 22.83 & 0.61 & 46.80 & 97.20 & 32.37 & 8.62 & 3.06 & 25.10 & 0.89 \\
\hline P2 x P6 & 57.00 & 65.33 & 68.67 & 90.00 & 109.10 & 34.43 & 17.13 & 17.33 & 23.53 & 1.93 & 79.20 & 46.80 & 62.83 & 9.85 & 2.86 & 28.03 & 4.28 \\
\hline P2 x P7 & 56.33 & 62.67 & 65.67 & 89.00 & 96.13 & 13.80 & 5.77 & 8.00 & 22.90 & 2.27 & 121.20 & 33.60 & 77.40 & 9.79 & 2.65 & 26.60 & 10.86 \\
\hline P2 x P8 & 57.67 & 63.33 & 67.67 & 94.67 & 127.90 & 25.63 & 15.23 & 10.43 & 24.67 & 1.17 & 47.00 & 51.40 & 47.73 & 8.98 & 3.05 & 30.43 & 1.27 \\
\hline P2 x P9 & 58.67 & 65.67 & 71.33 & 88.00 & 143.77 & 33.20 & 13.57 & 19.63 & 25.00 & 1.58 & 68.40 & 57.20 & 54.97 & 9.75 & 3.04 & 31.20 & 5.22 \\
\hline $\mathrm{P} 2 \times \mathrm{P} 10$ & 57.00 & 64.00 & 68.67 & 87.33 & 145.47 & 31.33 & 16.10 & 15.23 & 25.20 & 2.22 & 89.00 & 48.40 & 64.80 & 9.26 & 3.12 & 28.60 & 8.61 \\
\hline $\mathrm{P} 2 \times \mathrm{P} 11$ & 55.33 & 60.33 & 64.67 & 84.67 & 140.43 & 33.03 & 17.20 & 15.77 & 26.77 & 1.83 & 68.00 & 62.00 & 52.20 & 9.45 & 3.03 & 27.47 & 5.39 \\
\hline $\mathrm{P} 2 \times \mathrm{P} 12$ & 56.00 & 62.00 & 67.33 & 89.00 & 136.67 & 47.43 & 16.67 & 30.77 & 26.83 & 2.11 & 77.40 & 53.00 & 59.33 & 8.38 & 3.04 & 31.77 & 4.99 \\
\hline P3 x P4 & 46.33 & 50.67 & 54.33 & 76.33 & 130.47 & 47.57 & 1.10 & 46.43 & 25.47 & 0.69 & 41.00 & 114.60 & 27.07 & 8.63 & 3.00 & 26.13 & 1.29 \\
\hline P3 x P5 & 49.00 & 56.33 & 61.33 & 81.00 & 138.90 & 32.90 & 17.33 & 15.57 & 24.03 & 0.46 & 13.00 & 125.60 & 9.40 & 7.67 & 2.60 & 26.67 & 0.86 \\
\hline P3 x P6 & 49.33 & 55.67 & 63.33 & 85.33 & 145.57 & 32.23 & 8.47 & 23.77 & 24.00 & 0.76 & 34.40 & 90.00 & 24.97 & 8.54 & 3.06 & 24.63 & 2.86 \\
\hline P3 x P7 & 37.67 & 44.33 & 52.00 & 76.00 & 148.13 & 43.70 & 20.57 & 23.13 & 24.83 & 1.69 & 79.80 & 45.40 & 63.80 & 9.05 & 3.02 & 27.10 & 17.23 \\
\hline P3 x P8 & 40.00 & 46.00 & 52.33 & 60.00 & 151.87 & 40.77 & 0.00 & 40.77 & 25.53 & 0.40 & 0.00 & 182.60 & 0.00 & 0.00 & 0.00 & 0.00 & 0.00 \\
\hline P3 x P9 & 38.33 & 44.33 & 52.00 & 83.00 & 163.10 & 54.20 & 1.57 & 52.67 & 24.63 & 0.81 & 5.20 & 180.20 & 2.90 & 9.36 & 3.40 & 27.50 & 0.47 \\
\hline P3 x P10 & 42.00 & 49.00 & 54.33 & 75.33 & 159.87 & 16.57 & 7.23 & 9.33 & 27.20 & 0.70 & 6.60 & 196.40 & 3.27 & 7.66 & 3.30 & 25.40 & 0.88 \\
\hline P3 x P11 & 36.00 & 42.33 & 49.00 & 60.00 & 153.77 & 43.43 & 0.00 & 43.43 & 25.93 & 0.74 & 0.00 & 212.80 & 0.00 & 0.00 & 0.00 & 0.00 & 0.00 \\
\hline P3 x P12 & 44.00 & 48.00 & 54.00 & 74.00 & 169.10 & 55.23 & 0.33 & 54.90 & 26.10 & 0.58 & 3.40 & 210.80 & 1.67 & 8.13 & 3.40 & 38.10 & 1.20 \\
\hline G.M & 56.11 & 62.97 & 67.36 & 84.42 & 130.95 & 30.33 & 13.72 & 16.60 & 24.72 & 2.18 & 83.10 & 71.10 & 54.74 & 8.61 & 2.83 & 26.44 & 12.05 \\
\hline S.E & 2.63 & 2.51 & 2.47 & 4.44 & 4.51 & 6.39 & 3.37 & 5.56 & 0.88 & 0.31 & 11.39 & 8.95 & 5.60 & 0.13 & 0.04 & 1.06 & 2.83 \\
\hline SE M.D & 3.69 & 3.57 & 3.52 & 5.44 & 6.31 & 8.71 & 4.78 & 7.69 & 1.22 & 0.45 & 13.22 & 12.27 & 5.96 & 0.18 & 0.06 & 1.51 & 4.02 \\
\hline
\end{tabular}

Legend: BTN = days to 50\% booting, FLW = days to 50\% flowering, ANTS = days to $80 \%$ Anthesis, MTY = days to $80 \%$ maturity, PLHT $=$ Plant height (cm), TNT $=$ Total number of tillers, EFT = number of effective tillers, NEFT $=$ number of non-effective tillers, PAN.L $=$ Panicle length $(\mathrm{cm}), \mathrm{PAN} . \mathrm{W}=$ Panicle weight $(\mathrm{g}), \mathrm{FG}=$ number of filled grains per panicle, UFG = number of unfilled grains per panicle, $\% \mathrm{~F}=$ percentage fertility, SD.LHT $=$ Seed length $(\mathrm{mm}), \mathrm{SD} \cdot \mathrm{WTH}(\mathrm{mm})=\mathrm{Seed}$ width, $1000 \mathrm{GWH}=1000 \mathrm{grain}$ weight (g), Y/PLT = yield per plant $(\mathrm{g} / \mathrm{ha})$. 
Table 3. Estimates of genetic variance components and percentage contributions of lines, testers and their interaction to the total variation

\begin{tabular}{|c|c|c|c|c|c|c|c|c|c|c|c|c|c|c|c|c|c|}
\hline Parameter & BTN & FLW & ANTS & MTY & PLHT & TNT & EFT & NEFT & PAN.L & PAN.W & FG & UFG & F\% & SDLHT & SDWTH & 1000GWH & Y/PLT \\
\hline Line ( $\delta^{2}$ gca) & -0.82 & 2.52 & 0.01 & -7.80 & 70.10 & 19.04 & -9.16 & 38.08 & 1.28 & 0.36 & 757.04 & -20.58 & 132.87 & 0.44 & -0.03 & 3.58 & 11.78 \\
\hline Tester ( $\delta^{2}$ gca) & 70.38 & 79.37 & 59.79 & 189.14 & 181.64 & 38.92 & 16.16 & 119.89 & -0.09 & 0.67 & 1953.27 & 2729.66 & 679.66 & 2.33 & 0.01 & 10.67 & 13.37 \\
\hline Average ( $\delta^{2}$ gca) & 12.05 & 13.64 & 10.25 & 32.31 & 32.14 & 6.94 & 2.64 & 21.10 & 0.00 & 0.12 & 345.66 & 467.65 & 118.41 & 0.40 & 0.00 & 1.88 & 2.46 \\
\hline L x T $\left(\left(\delta^{2}\right.\right.$ sca $)$ & 207.17 & 241.01 & 186.85 & 925.78 & 799.62 & 169.27 & 63.69 & 407.02 & 1.65 & 2.41 & 6273.81 & 8575.63 & 2050.90 & 10.99 & 0.69 & 88.15 & 63.88 \\
\hline Env. Variance & 4.65 & 2.87 & 3.03 & 3.76 & 14.99 & 39.90 & 11.15 & 35.86 & 0.86 & 0.10 & 64.75 & 113.09 & 20.20 & 0.01 & 0.00 & 0.01 & 0.41 \\
\hline \multicolumn{18}{|c|}{$\mathrm{F}=0$ (Not inbred lines) } \\
\hline Additive variance & 3.01 & 3.41 & 2.56 & 8.08 & 8.03 & 1.74 & 0.66 & 5.27 & 0.00 & 0.03 & 86.42 & 116.91 & 29.60 & 0.10 & 0.00 & 0.47 & 0.61 \\
\hline Dominance variance & 103.58 & 120.51 & 93.43 & 462.89 & 399.81 & 84.63 & 31.84 & 203.51 & 0.82 & 1.20 & 3136.90 & 4287.82 & 1025.45 & 5.50 & 0.35 & 44.07 & 31.94 \\
\hline Gene action & 0.06 & 0.06 & 0.05 & 0.03 & 0.04 & 0.04 & 0.04 & 0.05 & 0.00 & 0.05 & 0.06 & 0.05 & 0.06 & 0.04 & 0.00 & 0.02 & 0.04 \\
\hline Dominance ratio & 0.17 & 0.17 & 0.17 & 0.13 & 0.14 & 0.14 & 0.14 & 0.16 & 0.03 & 0.16 & 0.17 & 0.17 & 0.17 & 0.14 & 0.02 & 0.10 & 0.14 \\
\hline Narrowsense $\left(h_{n}\right)$ & 0.03 & 0.03 & 0.03 & 0.02 & 0.02 & 0.01 & 0.02 & 0.02 & 0.00 & 0.02 & 0.03 & 0.03 & 0.03 & 0.02 & 0.00 & 0.01 & 0.02 \\
\hline Broadsense $\left(h_{b}\right)$ & 0.96 & 0.98 & 0.97 & 0.99 & 0.96 & 0.68 & 0.74 & 0.85 & 0.49 & 0.92 & 0.98 & 0.97 & 0.98 & 1.00 & 1.00 & 1.00 & 0.99 \\
\hline Genetic ad.* & 34.1 & 33.3 & 30.3 & 81.2 & 32.0 & 61.8 & 76.8 & 184.8 & 7.1 & 120.6 & 145.0 & 180.14 & 106.8 & 80.9 & 80.7 & 83.6 & 125.3 \\
\hline \multicolumn{18}{|l|}{ \%Contribution } \\
\hline Lines $(\%)$ & 9.68 & 13.35 & 13.19 & 22.66 & 32.11 & 33.71 & 9.42 & 30.18 & 62.63 & 38.05 & 33.52 & 12.89 & 22.56 & 27.40 & 28.21 & 30.79 & 43.27 \\
\hline Testers(\%) & 68.91 & 65.25 & 60.47 & 29.44 & 32.15 & 25.54 & 32.90 & 43.67 & 2.16 & 42.27 & 56.17 & 60.18 & 65.96 & 30.37 & 8.63 & 17.48 & 28.26 \\
\hline L x T (\%) & 21.41 & 21.40 & 26.35 & 47.90 & 35.74 & 40.75 & 57.68 & 26.15 & 35.38 & 19.64 & 10.31 & 26.93 & 11.48 & 42.23 & 63.35 & 51.72 & 28.47 \\
\hline
\end{tabular}

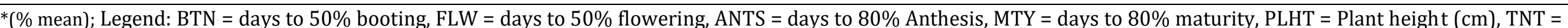

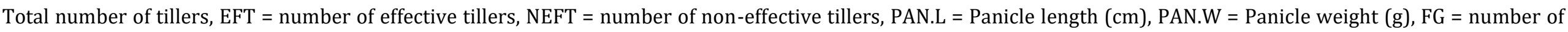

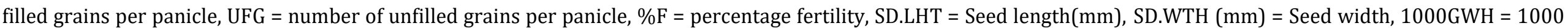
grain weight $(\mathrm{g}), \mathrm{Y} / \mathrm{PLT}=$ yield per plant $(\mathrm{g} / \mathrm{ha})$. 
Table 4. Estimates of general combining ability estimates effects for the seventeen characters studied.

\begin{tabular}{|c|c|c|c|c|c|c|c|c|c|c|c|c|c|c|c|c|c|}
\hline Lines & BTN & FLW & ANTS & MTY & PLHT & TNT & EFT & NEFT & PAN.L & PAN.W & $\mathrm{FG}$ & UFG & F\% & SD.LHT & SD.WTH & 1000GWH & Y/PLT \\
\hline $\mathrm{P} 4$ & $19.27^{* *}$ & $22.99^{* *}$ & $23.42^{* *}$ & $30.19 * *$ & $21.65^{* *}$ & $17.37^{* *}$ & 3.05 & $14.36^{* *}$ & $7.04^{* *}$ & $1.20^{* *}$ & $60.43^{* *}$ & 2.36 & $24.39 * *$ & $2.96^{* *}$ & $0.73^{* *}$ & $7.59^{* *}$ & $3.85^{* *}$ \\
\hline P5 & $12.38^{* *}$ & $13.77^{* *}$ & $14.64^{* *}$ & $22.07^{* *}$ & $21.66^{* *}$ & 3.48 & $4.76^{*}$ & -1.23 & $3.93^{* *}$ & $-0.46^{*}$ & $-10.02^{*}$ & $41.25^{* *}$ & $-6.42^{*}$ & $2.33^{* *}$ & $0.73^{* *}$ & $6.93^{* *}$ & $-2.63^{* *}$ \\
\hline P6 & $14.49^{* *}$ & $16.66^{* *}$ & $18.31^{* *}$ & $28.30^{* *}$ & $15.47^{* *}$ & 0.70 & 2.13 & -1.46 & $4.89^{* *}$ & $0.39 *$ & $18.98^{* *}$ & 5.92 & $13.88^{* *}$ & $3.06^{* *}$ & $0.83^{* *}$ & $6.81^{* *}$ & $1.03^{*}$ \\
\hline P7 & $14.16^{* *}$ & $15.66^{* *}$ & $16.75^{* *}$ & $26.96^{* *}$ & $29.80^{* *}$ & 0.26 & $5.42^{*}$ & -5.16 & $6.12^{* *}$ & $1.66^{* *}$ & $68.43^{* *}$ & $-20.64^{* *}$ & $37.65^{* *}$ & $3.3^{* *}$ & $0.68^{* *}$ & $6.93^{* *}$ & $9.84^{* *}$ \\
\hline P8 & $12.05^{\text {** }}$ & $12.77^{* *}$ & $14.08^{* *}$ & 0.41 & $39.63^{* *}$ & $7.26^{*}$ & 0.94 & 6.28 & $6.55^{* *}$ & -0.35 & $-16.57^{* *}$ & $30.47^{* *}$ & -0.97 & $-0.28^{* *}$ & $-0.04^{* *}$ & $0.37^{* *}$ & $-2.95^{* *}$ \\
\hline P9 & $9.16^{* *}$ & $10.77^{* *}$ & $13.31^{* *}$ & $23.74^{* *}$ & $49.44^{* *}$ & $13.48^{* *}$ & 0.02 & $13.51^{* *}$ & $5.42^{* *}$ & -0.05 & -3.46 & $30.47^{* *}$ & 4.34 & $-3.23^{* *}$ & $1.08^{* *}$ & $9.93^{* *}$ & $-1.24^{* *}$ \\
\hline P10 & $12.71^{* *}$ & $14.66^{* *}$ & $15.42^{* *}$ & $23.85^{* *}$ & $43.96^{* *}$ & 3.04 & $5.98^{* *}$ & -2.90 & $7.91^{* *}$ & $0.74^{* *}$ & $23.43^{* *}$ & $29.25^{\text {** }}$ & $13.95^{* *}$ & $2.48^{* *}$ & $1.14^{* *}$ & $9.93^{* *}$ & $4.75^{* *}$ \\
\hline P11 & $11.94^{* *}$ & $12.99 * *$ & $14.08^{* *}$ & -1.15 & $32.03^{* *}$ & $10.81^{* *}$ & 1.05 & $9.80^{* *}$ & $6.71^{* *}$ & 0.28 & 0.20 & $37.81^{* *}$ & $6.76^{*}$ & $-0.17^{*}$ & $-0.06^{* *}$ & $-1.96^{* *}$ & $-1.53^{* *}$ \\
\hline $\mathrm{P} 12$ & $11.71^{* *}$ & $12.44^{* *}$ & $13.75^{* *}$ & $23.41^{* *}$ & $49.07^{* *}$ & $18.04^{* *}$ & 2.61 & $15.40^{* *}$ & $7.88^{* *}$ & 0.34 & $12.98^{* *}$ & $42.92^{* *}$ & $7.65^{* *}$ & $2.25^{* *}$ & $1.12^{* *}$ & $13.15^{\text {** }}$ & $2.49 * *$ \\
\hline $\operatorname{SE}\left(g_{i}\right)$ & 1.24 & 0.98 & 1.00 & 1.12 & 2.24 & 3.65 & 1.93 & 3.46 & 0.54 & 0.19 & 4.65 & 6.14 & 2.59 & 0.07 & 0.00 & 0.06 & 0.37 \\
\hline SE $\left(g_{i-} g_{j}\right)$ & 1.76 & 1.38 & 1.42 & 1.58 & 3.16 & 5.16 & 2.73 & 4.89 & 0.76 & 0.26 & 6.57 & 8.68 & 3.67 & 0.09 & 0.00 & 0.08 & 0.52 \\
\hline \multicolumn{18}{|l|}{$t^{*} \mathrm{df}=8$} \\
\hline \multicolumn{18}{|l|}{ Testers } \\
\hline P1 & $4.07^{* *}$ & $4.57^{* *}$ & $3.94^{* *}$ & $6.49^{* *}$ & $-7.46^{* *}$ & $-4.57^{* *}$ & $2.04^{*}$ & $-6.62^{* *}$ & 0.08 & $0.57^{* *}$ & $30.04^{* *}$ & $-22.61^{* *}$ & $13.74^{* *}$ & $0.85^{* *}$ & $0.12^{* *}$ & $1.95^{* *}$ & $3.24^{* *}$ \\
\hline P2 & $3.32^{* *}$ & $3.27^{* *}$ & $2.92^{* *}$ & $6.85^{* *}$ & $-5.04^{* *}$ & -1.13 & $1.90^{*}$ & $-3.01^{*}$ & -0.24 & 0.11 & $6.15^{* *}$ & $-23.94^{* *}$ & $8.92^{* *}$ & $0.60^{* *}$ & $0.14^{* *}$ & $1.59^{* *}$ & $-0.78^{* *}$ \\
\hline P3 & $-7.40^{* *}$ & $-7.84^{* *}$ & $-6.86^{* *}$ & $-13.34^{* *}$ & $12.50^{* *}$ & $5.70^{* *}$ & $-3.94^{* *}$ & $9.64^{* *}$ & 0.16 & $-0.68^{* *}$ & $-36.19^{* *}$ & $46.56^{* *}$ & $-22.66^{* *}$ & $-1.45^{* *}$ & $-0.25^{* *}$ & $-3.55^{* *}$ & $-2.47^{* *}$ \\
\hline $\operatorname{SE}\left(g_{i}\right)$ & 0.62 & 0.49 & 0.50 & 0.56 & 1.12 & 1.82 & 0.96 & 1.73 & 0.27 & 0.09 & 2.32 & 3.07 & 1.30 & 0.03 & 0.00 & 0.03 & 0.18 \\
\hline SE $\left(g-i g_{j}\right)$ & 0.88 & 0.69 & 0.71 & 0.79 & 1.58 & 2.58 & 1.36 & 2.44 & 0.38 & 0.13 & 3.28 & 4.34 & 1.83 & 0.05 & 0.00 & 0.04 & 0.26 \\
\hline$t^{*} d f=35$ & 1.80 & 1.41 & 1.45 & 1.62 & 3.23 & 5.27 & 2.78 & 4.99 & 0.77 & 0.27 & 6.71 & 8.87 & 3.75 & 0.10 & 0.00 & 0.08 & 0.53 \\
\hline
\end{tabular}

*: significant at $\mathrm{p}<0.05 ;{ }^{* *}$ : significant at $\mathrm{p}<0.01$.

Legend: $\mathrm{BTN}=$ days to $50 \%$ booting, FLW $=$ days to $50 \%$ flowering, ANTS $=$ days to $80 \%$ Anthesis, MTY $=$ days to $80 \%$ maturity, PLHT $=$ Plant height $(\mathrm{cm})$, TNT $=$ Total number of tillers, $\mathrm{EFT}=$ number of effective tillers, NEFT $=$ number of non-effective tillers, PAN.L $=$ Panicle length $(\mathrm{cm}), \mathrm{PAN} . \mathrm{W}=\mathrm{Panicle}$ weight $(\mathrm{g}), \mathrm{FG}=$ number of filled grains per panicle, UFG = number of unfilled grains per panicle, $\% \mathrm{~F}=$ percentage fertility, SD.LHT $=$ Seed length $(\mathrm{mm}), \mathrm{SD} . \mathrm{WTH}(\mathrm{mm})=\mathrm{Seed}$ width, $1000 \mathrm{GWH}=1000$ grain weight $(\mathrm{g}), \mathrm{Y} / \mathrm{PLT}=$ yield per plant $(\mathrm{g} / \mathrm{ha})$. 
Table 5. Estimates of specific combining ability effect for the seventeen characters studied.

\begin{tabular}{|c|c|c|c|c|c|c|c|c|c|c|c|c|c|c|c|c|c|}
\hline Hybrids & BTN & FLW & ANTS & MTY & PLHT & TNT & EFT & NEFT & PAN.L & PAN.W & $\mathrm{FG}$ & UFG & $\mathrm{F} \%$ & SD.LHT & SD.WTH & 1000GWH & Y/PLT \\
\hline $\mathrm{P} 1 \times \mathrm{P} 4$ & 2.04 & $8.20^{* *}$ & $9.39 * *$ & $5.06^{* *}$ & $11.54^{* *}$ & 4.69 & 5.14 & -0.49 & 1.00 & $1.10^{* *}$ & $58.41^{* *}$ & -16.72 & $15.23^{* *}$ & $-0.28^{*}$ & $-0.13^{* *}$ & $-1.06^{* *}$ & $8.62^{* *}$ \\
\hline P1 x P5 & 1.59 & -0.57 & -1.17 & $-4.49 *$ & $-26.57^{* *}$ & -0.43 & -2.34 & 1.77 & -1.45 & -0.06 & -6.81 & 15.72 & -0.84 & $0.26^{*}$ & $-0.18^{* *}$ & -0.06 & -1.18 \\
\hline P1 x P6 & -2.85 & $-3.80 *$ & $-3.50 *$ & $-6.71^{* *}$ & $-14.48^{* *}$ & $-10.98^{*}$ & $-6.04^{*}$ & -5.01 & -0.21 & 0.01 & -2.81 & $31.06^{* *}$ & -6.30 & $-0.39 * *$ & $-0.24 * *$ & $-1.29 * *$ & 0.74 \\
\hline P1 x P7 & $8.81^{* *}$ & $8.20^{* *}$ & $7.72^{* *}$ & 0.95 & $24.66^{* *}$ & -2.54 & -0.23 & -2.41 & $2.06^{*}$ & $1.28^{* *}$ & 8.74 & $35.61^{* *}$ & $-12.12^{* *}$ & $-0.50^{* *}$ & $-0.29 * *$ & $-2.06^{* *}$ & $-2.57^{* *}$ \\
\hline P1 x P8 & 0.93 & 0.09 & 0.06 & $18.18^{* *}$ & $8.70^{*}$ & 2.13 & 1.92 & 0.36 & 0.46 & -0.35 & -7.26 & -17.17 & 4.04 & $2.34^{* *}$ & $0.89^{* *}$ & $7.82^{* *}$ & $-1.35^{*}$ \\
\hline P1 x P9 & $-4.19^{*}$ & $-4.57^{* *}$ & $-4.83^{* *}$ & $-11.49^{* *}$ & 1.22 & -6.09 & 0.18 & -6.30 & -1.22 & -0.56 & -7.70 & $-20.83^{*}$ & 4.57 & $-0.77^{* *}$ & $-0.25^{* *}$ & $-1.06^{* *}$ & $-2.34^{* *}$ \\
\hline P1 x P10 & 0.93 & 0.20 & -0.28 & -2.94 & $-8.17^{*}$ & $12.69^{*}$ & 3.88 & 8.66 & 0.98 & 0.48 & $24.07^{* *}$ & $-30.28^{* *}$ & $13.53^{* *}$ & -0.07 & $-0.13^{* *}$ & $3.60^{* *}$ & $5.83^{* *}$ \\
\hline P1 x P11 & $7.04^{* *}$ & $7.20^{* *}$ & $6.39 * *$ & $25.06^{* *}$ & $-20.90^{* *}$ & -0.43 & 0.14 & -0.60 & $-1.73^{*}$ & -0.09 & 5.30 & $-43.50^{* *}$ & $15.05^{* *}$ & $2.09^{* *}$ & $0.86^{* *}$ & $6.16^{* *}$ & $-2.62^{* *}$ \\
\hline P1 x P12 & -2.07 & -1.24 & -1.94 & $-4.16^{*}$ & 1.59 & $-12.31^{*}$ & 3.48 & $-15.86^{* *}$ & 0.34 & -0.09 & $18.19^{*}$ & $-21.94^{*}$ & $8.05^{*}$ & -0.14 & $-0.20^{* *}$ & $-5.95^{* *}$ & $4.61^{* *}$ \\
\hline $\mathrm{P} 2 \times \mathrm{P} 4$ & 2.79 & 0.51 & 0.75 & $-5.30^{* *}$ & -6.93 & -4.09 & 1.51 & -5.77 & -0.46 & -0.03 & $-23.70^{* *}$ & 17.61 & -6.81 & $-0.48^{* *}$ & $-0.33^{* *}$ & $-1.04^{* *}$ & $-4.00^{* *}$ \\
\hline P2 x P5 & $-6.32^{* *}$ & $-5.60 * *$ & $-4.47^{* *}$ & $-8.52^{* *}$ & $22.72^{* *}$ & 1.80 & -5.52 & 7.27 & 0.33 & -0.28 & -0.93 & 13.39 & -3.88 & $-0.67^{* *}$ & $0.13^{* *}$ & $-3.37^{* *}$ & -0.24 \\
\hline P2 x P6 & -0.10 & 1.18 & -0.47 & $-4.41^{*}$ & -2.22 & 9.91 & 4.44 & 5.60 & 0.07 & 0.19 & 2.74 & -1.94 & 6.30 & -0.17 & $-0.18^{* *}$ & $-0.26^{* *}$ & -0.50 \\
\hline P2 x P7 & -0.44 & -0.49 & -1.92 & $-4.07 *$ & $-29.56^{* *}$ & -10.31 & $-10.19^{* *}$ & -0.02 & $-1.79^{*}$ & $-0.75^{*}$ & -4.70 & 11.61 & -2.92 & $-0.40^{* *}$ & $-0.24^{* *}$ & $-1.70^{* *}$ & $-2.75^{* *}$ \\
\hline P2 x P8 & 3.01 & 3.06 & 2.75 & $28.15^{* *}$ & $-7.58^{*}$ & -5.31 & 3.73 & -9.02 & -0.46 & 0.17 & 5.96 & $-21.83^{*}$ & 6.07 & $2.30^{* *}$ & $0.89^{* *}$ & $8.52^{* *}$ & 0.47 \\
\hline P2 x P9 & $6.90^{* *}$ & $7.40^{* *}$ & $7.19^{* *}$ & -1.85 & -1.52 & -3.87 & 2.99 & -7.02 & 0.99 & 0.27 & $14.19^{*}$ & -15.83 & $7.97^{*}$ & $-0.44^{* *}$ & $-0.25^{* *}$ & -0.04 & $2.69 * *$ \\
\hline P2 x P10 & 1.68 & 1.84 & 2.42 & -2.63 & 5.62 & 4.57 & -0.41 & 4.94 & -1.27 & 0.13 & 7.96 & $-23.61^{*}$ & $8.22 *$ & -0.18 & $-0.22^{* *}$ & $-2.70^{* *}$ & 0.10 \\
\hline P2 x P11 & 0.79 & -0.16 & -0.25 & $19.70^{* *}$ & $12.56^{* *}$ & -1.54 & $5.62^{*}$ & -7.21 & 1.49 & 0.20 & 10.19 & $-18.50^{*}$ & 2.79 & $2.66^{* *}$ & $0.89^{* *}$ & $7.85^{* *}$ & $3.16^{* *}$ \\
\hline P2 x P12 & 1.68 & 2.06 & 2.75 & -0.52 & $-8.26^{*}$ & 5.57 & 3.51 & 2.20 & 0.38 & 0.42 & 6.74 & $-32.61^{* *}$ & $9.01 *$ & $-0.83^{* *}$ & $-0.27^{* *}$ & $-2.93^{* *}$ & $-1.26^{*}$ \\
\hline P3 x P4 & $-4.82 *$ & $-8.71^{* *}$ & $-10.14^{* *}$ & 0.23 & -4.61 & -0.26 & $-6.65^{*}$ & 6.25 & -0.55 & $-1.08^{* *}$ & $-34.70^{* *}$ & -0.89 & $-8.42^{*}$ & $0.75^{* *}$ & $0.46^{* *}$ & $2.10^{* *}$ & $-4.62^{* *}$ \\
\hline P3 x P5 & $4.73^{*}$ & $6.18^{* *}$ & $5.64^{* *}$ & $13.01^{* *}$ & 3.84 & -1.04 & $7.86^{*}$ & -9.04 & 1.12 & 0.35 & 7.74 & $-28.78^{* *}$ & 4.72 & $0.41^{* *}$ & $0.05^{* *}$ & $3.44^{* *}$ & $1.42^{*}$ \\
\hline P3 x P6 & 2.95 & 2.62 & $3.97^{*}$ & $11.12^{* *}$ & $16.70^{* *}$ & 1.07 & 1.60 & -0.60 & 0.13 & -0.20 & 0.07 & $-29.11^{* *}$ & 0.00 & $0.57^{* *}$ & $0.42^{* *}$ & $1.55^{* *}$ & -0.24 \\
\hline P3 x P7 & $-8.38^{* *}$ & $-7.71^{* *}$ & $-5.81^{* *}$ & 3.12 & 4.90 & $12.85^{*}$ & $10.42^{* *}$ & 2.44 & -0.27 & $-0.54^{*}$ & -4.04 & $-47.22^{* *}$ & $15.03^{* *}$ & $0.90^{* *}$ & $0.53^{* *}$ & $3.77^{* *}$ & $5.52^{* *}$ \\
\hline P3 x P8 & -3.94 & -3.16 & -2.81 & $-46.32^{* *}$ & -1.12 & 2.85 & $-5.65^{*}$ & 8.66 & 0.01 & 0.18 & 1.30 & $39.00 * *$ & $-10.11^{*}$ & $-4.64^{* *}$ & $-1.77^{* *}$ & $-16.68^{* *}$ & 0.89 \\
\hline P3 x P9 & -2.17 & -2.82 & -2.36 & $13.34^{* *}$ & 0.27 & 10.30 & -3.17 & $13.33^{*}$ & 0.23 & 0.29 & -6.48 & $36.67^{* *}$ & $-12.54^{* *}$ & $1.21^{* *}$ & $0.50^{* *}$ & $1.44^{* *}$ & -0.35 \\
\hline P3 x P10 & -2.60 & -2.05 & -2.14 & $5.56^{* *}$ & 2.54 & $-16.93^{* *}$ & -3.47 & $-13.60^{*}$ & -0.29 & $-0.61^{*}$ & $-32.04^{* *}$ & $53.89^{* *}$ & $-21.75^{* *}$ & $0.25^{*}$ & $0.34^{* *}$ & $-0.90^{* *}$ & $-5.93^{* *}$ \\
\hline P3 x P11 & $-7.82^{* *}$ & $-7.05^{* *}$ & $-6.14^{* *}$ & $-44.77^{* *}$ & $8.34^{*}$ & 1.96 & $-5.77^{*}$ & 7.81 & 0.24 & -0.11 & $-15.48^{*}$ & $61.67^{* *}$ & $-17.84^{* *}$ & $-4.75^{* *}$ & $-1.75^{* *}$ & $-14.34^{* *}$ & -0.54 \\
\hline P3 x P12 & 0.40 & -0.82 & -0.81 & $4.68^{* *}$ & $6.63^{*}$ & 6.74 & $-6.99 *$ & $13.66^{*}$ & -0.72 & -0.33 & $-24.93^{* *}$ & $54.56^{* *}$ & $-17.06^{* *}$ & $0.96^{* *}$ & $0.47^{* *}$ & $8.55^{* *}$ & $-3.35^{* *}$ \\
\hline SE (sca effect & ct) 2.16 & 1.70 & 1.74 & 1.94 & 3.87 & 6.32 & 3.34 & 5.99 & 0.93 & 0.32 & 8.05 & 10.63 & 4.49 & 0.12 & 0.00 & 0.10 & 0.64 \\
\hline SE (Sij-Skl) & 3.05 & 2.40 & 2.46 & 2.74 & 5.48 & 8.93 & 4.72 & 8.47 & 1.31 & 0.45 & 11.38 & 15.04 & 6.36 & 0.16 & 0.00 & 0.14 & 0.91 \\
\hline
\end{tabular}
$\mathrm{t}^{*} \mathrm{df}=76$

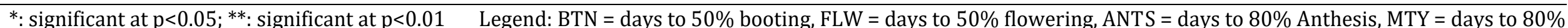
maturity, PLHT = Plant height $(\mathrm{cm})$, TNT $=$ Total number of tillers, EFT = number of effective tillers, NEFT = number of non-effective tillers, PAN.L = Panicle length $(\mathrm{cm})$ PAN.W = Panicle weight (g), FG = number of filled grains per panicle, UFG = number of unfilled grains per panicle, \%F = percentage fertility, SD.LHT = Seed length(mm),

SD.WTH $(\mathrm{mm})=$ Seed width, 1000GWH = 1000 grain weight $(\mathrm{g}), \mathrm{Y} / \mathrm{PLT}=$ yield per plant $(\mathrm{g} / \mathrm{ha})$. 


\section{ACKNOWLEDGEMENT}

I want to express my appreciation to the Sierra Leone Agricultural Research Institute (SLARI) and the West African Agricultural Productivity Programme (WAAPP) for providing the financial support to undergo this research.

\section{REFERENCES}

Ahmadikhah A, (2008). Estimation of heritability and heterosis of some agronomic traits and combining ability of rice lines using line $\mathrm{x}$ tester method. Electronic Journal of Crop Production 1(2): 15-33.

Aslam R, Munawar M, Salam A (2014). Genetic architecture of yield components accessed through Line $\mathrm{x}$ Tester analysis in wheat (Triticum aestivum L.) Universal Journal of Plant Science 2: 93-96.

Borghi B, Perenzin M, (1994). Diallel analysis to predict heterosis and combining ability for grain yield, yield components and bread-making quality in bread wheat (Triticum aestivum L.). Theoretical and Applied Genetics 89 (7-8): 975 - 981.

Devi A, Kumari P, Dwivedi R, Dwivedi S, Mishra KK, Verma OP, Singh PK, Dwivedi DK, (2017). Combining ability analysis for yield and its quality traits in rice (Oryza sativa L.) over environment. Journal of Pharmacognosy and Phytochemistry 6(4): $35-42$.

Falconer DS, Mackay TFC (1996). Introduction to Quantitative Genetics, 4th edition, Longman, Harlow, Essex, UK.

Fahmi AI, Eissa Ragaa A, Nagaty HH, El-Malky M, Sherif AI (2017). Genetic components and correlation coefficient for earliness and grain yield in rice. Vegetos 30:4

Fellahi ZEA, Hannachi A, Bouzerzour H, Boutekrabt A (2013). Line $\times$ tester mating design analysis for grain yield and yield related traits in bread wheat (Triticum aestivum L.). International Journal of Agronomy 1-9.

Gholizadeh AG, Nematzadeh G, Bagheri N, Oladi M, Bagheri A (2014). Heritability and heterosis of agronomic traits in rice lines. International Journal of Farming and Allied Sciences 3(1):66 70.

Gnanasekaran M, Vivekanandan P, Muthuramu S, (2006). Combining ability and heterosis for yield and grain quality in two line rice (Oryza sativa L.) hybrids. Indian Journal of Human Genetics 66: 6 9.

Gopikannan M, Ganesh SK (2013). Investigation on combining ability and heterosis for sodicity tolerance in rice (Oryza sativa L.). African Journal of Agricultural Research 8(32): 4326 - 4333.

Kempthorne 0. 1957. An introduction to genetic statistics. John Wiley \& Sons.

Koze A, (2017). Gene action and combining ability in line $\mathrm{x}$ tester population of safflower (Carthamus tinctorious L.). Field crops 22 (2): 197 - 203.

Kumar M, Kumar K, Verma GP, Verma OP (2010). Combining ability analysis for yield and components traits under saline alkaline soil in rice. Oryza, 47 (3): $193-200$.

Manickavelu A, Gnanamalar RP, Nadarajan N, Ganesh SK (2006). Genetic variability studies on different genetic populations of rice under drought condition. Journal of Plant Sciences 1(4): 332-339.

Patial M, Pal D, Kumar J (2016). Combining ability and gene action studies for grain yield and its components traits in Barley (Hordeum vulgare L.). SABRAO Journal of Breeding and Genetics 48(1): $90-96$.

Peng JY, Virmani SS (1990). Combining ability for yield and four yield related traits in relation to breeding rice. Oryza 27: 1-10.

Pradhan SK, Boss LK, Meher J (2006). Studies on gene action and combining ability analysis in Basmati rice. Journal of Centeral European Agriculture 7(2): 267-272.

Premlatha M, Kalamani A, Nirmalakumari A (2011). Heterosis and combining ability for grain yield and quality in maize (Zea mays L.). Advances in Environmental Biology 5(6): 1264-1266.

Rahaman A, (2016). Study of nature and magnitude of gene action in hybrid rice (Oryza sativa L.) through experiment of line $\mathrm{x}$ tester mating design. International Journal of Applied Research 2(2):405-410.

Sarma MK, Sharma AK, Agrawal RK, Richharia AK (2007). Combining ability and gene action for yield and quality traits in Ahu rices of Assam. Indian Journal of Genetics and Plant Breeding 67 (3): 278-280.

Shanthi P, Jebaraj S, Geetha S (2011). Study on gene action for sodic tolerance traits in rice (Oryza 
sativa L.). Electronic Journal of Plant Breeding 2(1): 24-30.

Simmonds NW (1989). How frequent are superior genotypes in plant breeding populations. Biological Review 64: 341-365.

Singh R, Singh H (1985). Combining ability and heterosis for seed yield, its component characteristics in indian mustard sown early and late. Indian Journal Agricultural Sciences 55: 309 - 315.

Singh RJ, Maurya A (1999). Evaluation of CMS lines for various floral traits influence outcrossing in rice. International Rice Research Notes 28: 24-26.

Thirumalai R, Palaniraja K, Vennila S (2018). Yield response of rice genotypes for gene action under coastal saline condition. International Journal of Current Microbiology and Applied Sciences 7(4): 3353 - 3360.

Vanave PB, Vaidya GB, Jadhav BD (2018). Combining ability of rice genotypes under coastal saline conditions. Electronic Journal of Plant Breeding 9(1): 116-123.

Zhang X, Liangiie LV, Chai LV, Baojian G, Rugen X (2015). Combining ability of different agronomic traits and yield components in hybrid barley. Plos One 10: 6 . 